American Journal of Immunology 2 (1): 8-11 2006

ISSN 1553-619X

(c) 2006 Science Publications

\title{
Na,K-ATPase $\alpha$ Subunit-like Immunoreactive Proteins in Human Body Fluids
}

\author{
Jeng-Hsiung F. Peng \\ Department of Molecular Biology and Biochemistry, National Chiayi University, Chiayi, Taiwan 60004
}

\begin{abstract}
Na,K-ATPase was recently considered a target for breast cancer treatment since its potent inhibitors ouabain and related digitalis compounds that were reported circulating in body fluids before, were found to possess potent anti-breast cancer activity. Based on this finding, it is hypothesized that $\mathrm{Na}, \mathrm{K}-\mathrm{ATPa} e$ derivatives could be circulating in the body and potential candidate biomarkers for early disease detection. Western blotting analysis was employed to investigate the possible presence of $\mathrm{Na}$,K-ATPase-like proteins in cerebrospinal fluid (CSF) and plasma using previously prepared antisera against $\mathrm{Na}, \mathrm{K}$-ATPase $\alpha$ subunit and its formic acid-derived fragments. Results from this analysis show that human $\mathrm{Na}, \mathrm{K}$-ATPase $\alpha$ subunit-like immunoreactive proteins with apparent molecular weights of 97, 68, 66, 57 and $55 \mathrm{kDa}$ in the CSF, as well as 68, 66, 57 and $55 \mathrm{kDa}$ in the plasma have been identified. By combining immunoaffininty binding and electroelution, these immunoreactive proteins were purified from human body fluids. This is the first report of the presence in the body fluids of immunoreactive proteins cross-reacted with anti-human Na,K-ATPase catalytic $\alpha$ subunit antibodies. These results suggest that these proteins are probably $\mathrm{Na}, \mathrm{K}$-ATPase derivatives resulting from degradation and released in vivo during cellular metabolism.
\end{abstract}

Key words: Na,K-ATPase, $\alpha$ subunit, CSF, plasma, Western blot, Immunoaffinity binding

\section{INTRODUCTION}

Novel biomarkers in human body fluids that could assist in the accurate diagnosis and detection of the earliest phase of cancer and neurodegenerative diseases as well as medical management of these illnesses are currently under intense study ${ }^{[1]}$. Many enzymes, proteins and peptides were found in the cerebrospinal fluid (CSF) and other body fluids since it was reported that serum aldolase activity is increased in patients with progressive muscular dystrophy ${ }^{[2]}$. Because CSF and plasma protein compositions mirror proteins in the brain and in the body under healthy and diseased states, the presence of proteins in human body fluids is clinically significant. Notably, a soluble counterpart of the $\beta$-amyloid protein ( $\beta \mathrm{AP})$, which appeared as insoluble protein aggregates in the cores of senile plaques in the brains of Alzheimer disease (AD) patients, as well as its precursor, $\beta A P P$, from which $\beta \mathrm{AP}$ is derived, has been found in the $\mathrm{CSF}^{[3-5]}$. Besides beta-amyloid and amyloid precursor proteins, other proteins and peptides known to be involved in neurodegenerative diseases are normal tau and phosphorylated tau, synaptic proteins, as well as apolipoprotein $\mathrm{E}^{[6]}$. Elevated levels of S100beta protein in the CSF and serum after head trauma, subarachnoid hemorrhage and stroke have been found to correlate with extent of brain damage ${ }^{[7]}$. Brain Na,K-ATPase activity, along with ouabain binding sites, have been found to be reduced in $\mathrm{AD}^{[8,9]}$. An impaired cerebral energy metabolism due to abnormal sodium pump

function may result in exitotoxic neuronal degeneration in these diseases ${ }^{[10]}$. Recently, $\mathrm{Na}, \mathrm{K}$-ATPase has been proposed as a potentially important target for breast cancer treatment, since its potent inhibitors ouabain and related digitalis that were found previously in the body fluids ${ }^{[11,12]}$, seemed to possess potent anti-breast cancer activity $^{[13]}$. Accumulating evidence suggests the central nervous system as a site of synthesis, but also as a site of hypertensinogenic action of endogenous cardioglycosides ${ }^{[13]}$. It is thus hypothesized that variants of Na,K-ATPase, an important membrane protein of the sodium pump may be circulated in the body fluids during metabolic turnover and could be potential candidate biomarkers for early disease detection.

The possible presence of soluble derivatives of $\mathrm{Na}, \mathrm{K}-\mathrm{ATPase}$ in the CSF and plasma of PTC patients and controls was thus investigated by Western blotting employing polyclonal antisera to human $\mathrm{Na}, \mathrm{K}$-ATPase $\alpha$ subunits and formic acid-derived fragments previously prepared ${ }^{[14]}$. These antisera are highly specific, since they cross-reacted only with the $100 \mathrm{kDa}$ $\mathrm{Na}, \mathrm{K}-\mathrm{ATPase} \alpha$. subunit bands of the crude brainstem homogenates, axolemma and cerebral cortex synaptosomes and microsomes in immunoblotting and also successfully used for immunohistochemical staining of $\mathrm{Na}, \mathrm{K}$-ATPase containing fibers in the human frontal cortex ${ }^{[14]}$. The aim of this study is to

Corresponding Author: Jeng-Hsiung F. Peng, Department of Molecular Biology and Biochemistry, National Chiayi University, 300 Syuefu Road, Chiayi, Taiwan 60004 
determine whether of $\mathrm{Na}, \mathrm{K}$-ATPase $\alpha$ subunit-like proteins are present in biological fluids. This communication documenting the presence of novel, $\mathrm{Na}, \mathrm{K}$-ATPase catalytic $\alpha$ subunit-like immunoreactive

proteins in human body fluids with molecular weights close to formic acid-derived 40, 50 and $60 \mathrm{kDa}$ fragments by immunoblotting, immunoaffinity binding and electroelution.

\section{MATERIALS AND METHODS}

Nitrocellulose blots of 12 CSF samples of Pseudotumor cerebri (PTC) patients and controls ${ }^{[15]}$, as well as blots of plasma samples prepared from blood specimens of twelve other patients were used in this study. These samples were collected during treatment procedures with prior consent of the patients. Plasma samples were prepared from aged blood specimens of patients that were no longer needed for clinical uses.

Only blood specimens without visible hemolysis were centrifuged at $1000 \mathrm{x} \mathrm{g}$ for $5 \mathrm{~min}$. The plasma was carefully withdrawn with a Pasteur pipet. All samples were dialyzed extensively in phosphate-buffered saline, centrifuged at $60,000 \mathrm{x} \mathrm{g}$ for $45 \mathrm{~min}$ to remove the precipitate and stored frozen at $-20^{\circ} \mathrm{C}$ until used for Western blotting. Proteins were determined by the method of Lowry et al. ${ }^{[16]}$. Electrophoretic separation of the CSF and plasma proteins in the presence of SDS was performed using $10 \%$ polyacrylamide mini-gels, as described by Laemmli ${ }^{[17]}$. Western blot was carried out as previously reported ${ }^{[14,18]}$.

Antisera to $\mathrm{Na}, \mathrm{K}$-ATPase $\alpha$ subunit and formic acid-derived 40, 50 and $60 \mathrm{kDa}$ polypeptide fragments were prepared in New Zealand white rabbits ${ }^{[14,19]}$. R40 IgG antibodies used in this study were prepared from antiserum by ammonium sulfate precipitation at $40 \%$ saturation. The precipitate was dialyzed extensively in $20 \mathrm{mM}$ sodium phosphate buffer at $\mathrm{pH}$ 7.4. Crude antibody preparation $(8 \mathrm{ml})$ was further purified by applying to a DEAE-sepharose column $(1.5 \times 20 \mathrm{~cm})$. IgG fractions were pooled and concentrated.

Immunoaffinity resin was prepared by coupling R40 IgG, which were dialyzed extensively with $0.5 \mathrm{M}$ $\mathrm{NaCl} / 0.1 \mathrm{M} \mathrm{NaHCO} 3, \mathrm{pH}$ 8.3, to a freshly prepared cyanogen bromide-activated sepharose 4B (2 mg proteins/ml of resin) as previously described ${ }^{[20]}$. The immunogen, R40 IgG-sepharose, was suspended in buffer A $(0.5 \mathrm{M} \mathrm{NaCl} / 5 \mathrm{mM}$ EDTA/5 mM Tris- $\mathrm{HCl}$, $\mathrm{pH} 7.4, \& 0.02 \% \mathrm{NaN} 3$ ) and stored at $4^{\circ} \mathrm{C}$ until used.

Immunoaffinity binding and electroelution techniques were employed for purification of human $\mathrm{Na}, \mathrm{K}-\mathrm{ATPase} \alpha$ subunit-like proteins from CSF and plasma as described ${ }^{[14]}$. CSF or plasma samples were dialyzed extensively with buffer A containing $0.5 \%$ Triton X-100 and incubated overnight at $4^{\circ} \mathrm{C}$ with $\mathrm{R} 40$ IgG-sepharose at 10:1 ratio. The mixture was centrifuged at $1000 \mathrm{x} \mathrm{g}$ for $1 \mathrm{~min}$ and the supernatant was removed. The immunoresin was washed five times with five volumes of buffer ( 5 min per washing); four times with buffer A containing $0.5 \%$ Triton X-100 and the last time with an elution buffer $(50 \mathrm{mM}$ NH4HCO3/0.1\% SDS, pH7.8). Electroelution was done at $10 \mathrm{~mA}$ current at $4^{\circ} \mathrm{C}$ for $3.5 \mathrm{hr}$, employing a BioRad electroeluter (Model 422). At the end of elution, the upper reservoir buffer and immunoresin was removed. The membrane cup containing eluted proteins, along with silicon gasket complex, was carefully removed from the eluter tube. The eluted proteins were recovered into three fractions, including the upper $(600 \mu \mathrm{l})$ and lower $(950 \mu \mathrm{l})$ fractions of the membrane cup. The third fraction was obtained from pooled washings of the membrane cup three times, each time with $50 \mu \mathrm{l}$ fresh elution buffer.

\section{RESULTS}

To study the possible presence of $\mathrm{Na}, \mathrm{K}$-ATPase $\alpha$ subunit-like immunoreactive proteins in body fluids, nitrocellulose (NC) blots containing bound CSF and plasma proteins from twelve samples per blot were incubated with R40 IgG overnight at $4^{\circ} \mathrm{C}$, followed by other immunobloting procedures ${ }^{[14]}$. Figure 1A shows intense staining of $55 \mathrm{KDa}$ bands were observed in almost all CSF samples (Lanes 1-2, 4-12), except Lane 3. Moderate staining of $68 \mathrm{KDa}$ bands were found in all samples. Weak staining of 57 and $66 \mathrm{KDa}$ bands scattered in some samples. Even weaker staining of 97 KDa bands was found in only two samples (Lanes 6 \& 8). Since Na,K-ATPase is present in many organs other than the brain, the presence of $\alpha$ subunit-like immunoreactive derivatives in the plasma was also examined. The pathological conditions of these twelve patients were unknown to the authors and were tested on Western blots using the same R40 IgG. Figure 1B reveals comparatively lighter staining than CSF was observed in all plasma samples. Again, $55 \mathrm{KDa}$ and 68 $\mathrm{KDa}$ bands show clear staining in almost every plasma sample (Lanes 1-12), except Lane 3. Slight visible staining of 66 bands was observed in some samples (Lanes 1-2 \& 4-5). However, no $97 \mathrm{kDa}$ band was observed in the plasma samples. Preimmune serum did not stain these bands at all (data not shown). Differences in immunoreactive patterns in either CSF or plasma samples of patients vs normal individuals were not compared this time, but will be addressed in later studies employing ELISA. To demonstrated specific immunolabeling, $1 \mu \mathrm{g}$ of the purified $40 \mathrm{kDa}$ plasma protein was incubated with $5 \mu \mathrm{l}$ of antiserum at $4^{\circ} \mathrm{C}$ overnight. The absorbed antiserum was centrifuged at $16,000 \mathrm{x} \mathrm{g}$ for $10 \mathrm{~min}$ and the supernatant was applied to the blot. The immunoreactivity was specific, since immunostaining was abolished in both cases (data not shown).

The existence of the $\mathrm{Na}, \mathrm{K}$-ATPase $\alpha$. subunit-like immunoreactive proteins in the CSF and plasma was 
further verified by purification from both sources using R40 IgG-sepharose $(1.0 \mathrm{ml})$ for binding these specific proteins, which were subsequently electroeluted. The advantage of combining immunoaffinity binding and electroelution is that proteins can be eluted in a

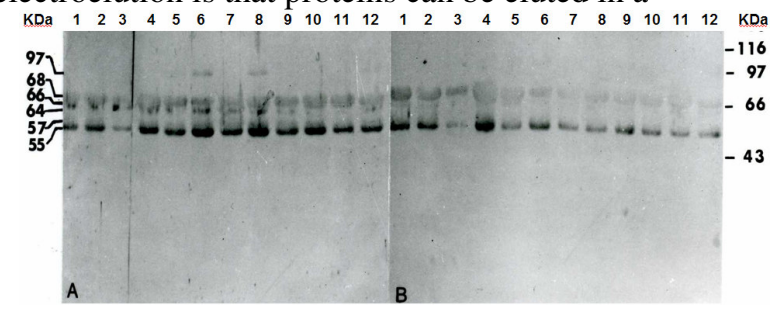

Fig. 1: Western blotting analysis of Na,K-ATPase $\alpha$ subunit-like protein derivatives in human cerebrospinal fluid (CSF) and plasma. Panel A: Lanes 1-8, CSF samples of pseudotumor cerebri patients; Lanes 9-12, CSF from patients with other illness. Panel B: Lanes 1-12, plasma samples from unknown patients. Antibodies to $\mathrm{Na}$,K-ATPase $\alpha$-subunit $40 \mathrm{KDa}$ formic acidderived fragment, R40 IgG, was used as an antibody probe.

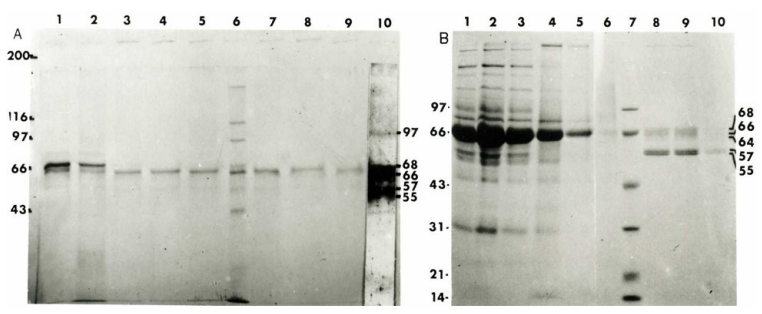

Fig. 2:Purification of Na,K-ATPase $\alpha$-subunit-like immunoreactive proteins from CSF and plasma samples by immunoaffinity binding and electroelution using R40 IgG-Sepharose. Panel A: CSF protein elution profile; Panel B: Plasma protein elution profile. Lanes 1-5 of CSF and lanes 2-6 of plasma fractions: non-specific proteins released from immunoaffinity resin during washing. Lanes 5A \& 6B: Proteins from the last washings were detected after concentration. Lanes7-9 (A) \& 8-10 (B) represent $\mathrm{Na}, \mathrm{K}$-ATPase-like immunoreactive proteins obtained from the upper fractions of the membrane cup (lane 7), the lower fractions (lane 8) and from further washings of the cup (lane 9). Most of proteins recovered from the lower membrane cup fraction (lanes 8A \& 9B). Coomassie blue staining shows that CSF samples contain 68 and $55 \mathrm{KDa}$ bands. Restaining of the same gel with silver ions revealed three additional bands, corresponding to MW of 97, 66 and $57 \mathrm{kDa}$, respectively (lane 10A).

concentrated form, avoiding the drawbacks of conventional elution of antigens bound to immunoaffinity resin. In this method, the sample was adjusted and dialyzed with buffer A containing $0.5 \%$ Triton X-100 to eliminate non-specific binding, then incubated with immunoaffinity resin at $37^{\circ} \mathrm{C}$ for $1 \mathrm{hr}$ or at $4^{\circ} \mathrm{C}$ overnight. After five consecutive washings, bound proteins were electroeluted and analyzed by SDS-PAGE. Figure 2 shows that Na,K-ATPase $\alpha$ subunit-like immunoreactive proteins were successfully purified from the CSF (A) and plasma (B). Lanes 1-5 of CSF and lanes 2-6 of plasma show non-specific proteins released from immunoaffinity resin during washing. They show that the amount of proteins decreased with each successive washing. Proteins from the last two washings (lanes 5A \& 6B) were detected after concentration. Lane $1 \mathrm{~B}$ shows the plasma protein profile before binding to immunoresin. Lanes 7-9 (A) \& 8-10 (B) respectively represent Na,K-ATPase-like immunoreactive proteins obtained from the upper fractions of the membrane cup [lanes 7(A) \& 8 (B)], the lower fractions [lanes 8 (A) \& 9 (B)] and from washings of the cup [lanes 9 (A) \& 10 (B)]. Most of the proteins $(80 \%)$ recovered from the lower membrane cup fraction (Fig. 2A, lane 8). Coomassie blue staining shows that CSF samples contain two bands, corresponding respectively to $\mathrm{MW}$ of 68 and $55 \mathrm{kDa}$ (Fig. 2A, lanes 7-9). Bands at $66 \mathrm{kDa}$ and $57 \mathrm{KDa}$ in lanes 7-9 are not apparent due to low protein concentration in these two fractions. Restaining of the same gel with silver ions revealed three additional bands, corresponding to MW of 97, 66 and $57 \mathrm{kDa}$, respectively (lane 10). On the other hand, the plasma samples contain two doublets with MW corresponding to 68 and $66 \mathrm{KDa}$ as well as 57 and $56 \mathrm{kDa}$ bands (Fig. 2B, lanes 8-10). The total CSF proteins applied to the immunoaffinity resin were only $1.2 \mathrm{mg}$, hence the purified proteins were concentrated by cold acetone in order to visualize on SDS-PAGE gel. Since larger amounts of plasma proteins were available, purification from plasma samples was much easier. Out of $320 \mathrm{mg}$ of plasma proteins applied, approximately $40 \mu \mathrm{g}$ of proteins were obtained.

\section{DISCUSSION}

The source of $\mathrm{Na}, \mathrm{K}$-ATPase $\alpha$. subunit-like immunoreactive proteins in human body fluids is probably derived from normal protein catabolism. It seems unlikely that these proteins were derived from contaminating cells or damaged membranes, since CSF and plasma samples that have been subjected to extensive dialysis followed by centrifugation at 60,000 $\mathrm{x} g$ for $45 \mathrm{~min}$, also contain these proteins. However, the presence in the CSF of a soluble protein of $97 \mathrm{kDa}$ (Fig. 1 and 2), which is close to the MW of the native $\alpha$ subunit proteins, is intriguing. It could be a newly released form of $\mathrm{Na}, \mathrm{K}-\mathrm{ATPase}$ derivative that has not subjecting to further degradation.

In this communication, at least five immunoreactive human $\mathrm{Na}, \mathrm{K}$-ATPase $\alpha$ subunit-like 
proteins were identified in either human CSF or plasma. Most of these previously unreported proteins in human body fluids have MW close to formic acid-derived 50 and $60 \mathrm{kDa}$ fragments of the human $\mathrm{Na}, \mathrm{K}$-ATPase $\alpha$ subunit. These soluble derivatives can be immunoprecipitated and purified. They probably represent products of degradation during Na,K-ATPase turnover. Whether these proteins in the CSF and plasma play any function or not is currently unknown. These proteins can be individually isolated and their identity confirmed by sequencing. We have no sequencing data on these proteins yet. N-terminal sequencing will reveal from which part of the $\alpha$ subunit these protein variants originate. The identification of $\alpha$ subunit-like immunoreactive proteins should facilitate studies of the metabolism of $\mathrm{Na}, \mathrm{K}$-ATPase in vitro and in vivo. Generation of these protein derivatives in body fluids could be significant physiologically. This discovery will allow characterization of proteins during disease processes through study of changes in their concentrations in the CSF or plasma and thus, it may have prognostic importance. If differences in concentrations in the body fluids between individuals and patients were found, they could provide us with valuable biochemical markers for diagnosis of cancer and neurodegenerative diseases.

\section{REFERENCES}

1. Galasko D. 2005 Biomarkers for Alzheimer's disease - Clinical needs and application. J. Alzheimers Dis. 8: 339-346.

2. Sibley JA, and Fleisher GA. 1954 The clinical significance of serum aldolase. Mayo Clin. Proc. 29: 591-603.

3. Burdick D, Soreghan B, Kwon M, Kosmoski J, Knauer M, Henschen A, Yates J, Cotman C, and Glabe C. 1992 Assembly and aggregation properties of synthetic Alzheimer,s A4/ amyloid peptide analogs. J. Biol. Chem. 267: 546-554.

4. Palmert, MR, Podlisny MB, Witker DS, Oltersdorf T, Younkin LH, Selkoe DJ, and Younkin SG. 1989 The -amyloid protein precursor of Alzheimer disease has soluble derivatives found in human brain and cerebrospinal fluid. Proc. Natl. Acad. Sci. USA. 86: 6338-6342.

5. Seubert P, Vigo-Pelfrey C, Esc F, Lee M, Dovey H, Davis D, Sinha S, Schlossmacher M, Whaley J, Swindlehurst C, McCormack R, Wolfert R, Selkoe D, Lieburg I, and Schenk D. 1992 Isolation and quantitation of soluble Alzheimer's peptide from biological fluids. Nature 359: 325-327.

6. Wallin AK, Blennow K, Andreasen N, and Mithon L. 2006 CSF biomarkers for AD: Levels of betaamyloid, tau, phosphorylated tau relate to clinical symptoms and survival. Dement. Geriatr. Cogn. Disord. 21: 131-138.
7. Kanner AA, Marchi N, Fezio V, Mayberg MR, Koltz MT, Siomin V, Stevens GH, Masaryk T, Ayumar B, Vogelbaum MA, Barnettm GH, Janigro GH. 2003 Serum S100 beta: a noninvasive marker of blood-brain barrier functions and brain lesions. Cancer 97: 2806-2813.

8. Harik SI, Mitchell M J, and Kalaria RN. 1989 Ouabain binding in the human brain: Effects of Alzheimer's disease and aging. Arch. Neurol. 46: 951-954.

9. Peng JH, and Parker JC Jr. 1991 Na,K-ATPase in Alzheimer brain. J. Neuropathol. Exp. Neurol. 50: 359.

10. Beal MF, Hyman BT, and Koroshetz W. 1993 Do defects in mitochondrial energy metabolism underlie the pathology of neurodegenerative diseases? TINS 16: 125-131.

11. Halperin JA, Martin AM, and Malave S. 1985 Increased digitalis-like activity in human cerebrospinal fluid after expansion of the extracellular fluid volume. Life Sci. 37: 561-566.

12. Lusic I, Ljutic D, Maskovic J, Jankovic S. 1999 Plasma and cerebrospinal fluid endogenous digoxin-like immunoreactivity in patients with aneurysmal subarachnoid haemorrhage. Acta Neurochir (Wien). 141: 691-697.

13. Chen JQ, Contreras RG, Wang R, Fernandez SV, Shoshani L, Russo IH, Cereijido M, Russo J. 2005 Sodium/potasium ATPase $(\mathrm{Na}(+), \mathrm{K}(+)$-ATPase) and ouabain/related cardiac glycosides: a new paradigm for development of anti- breast cancer drugs? Breast Cancer Res Treat. 2005 Dec 1-15.

14. Peng JH, Zeng YC, Tsai F, and Parker JC Jr. 1994 Purification and immunochemical properties of human brain Na,K-ATPase $\square$ subunits and formic acid-derived polypeptide fragments. Prep. Biochem. 24: 113-126.

15. Peng JH, Kung FT, Peng W, and Parker JC Jr, 2006 Increased ALZ-50 immunoreactivity in the CSF of pseudotumor cerebri patients. Ann. Clin. Lab. Sci. 36(2): 151-156.

16. Lowry OH, Rosebrough MJ, Farr NJ, and Randall R.J. 1951 Protein measurement with the Folin phenol reagent. J. Biol.Chem. 193: 265-275.

17. Laemmli UK. 1970 Cleavage of structural proteins during the assembly of the head of bacteriophage T4. Nature 227: 680-685.

18. Peng JH, Parker JC Jr, and Tsai F. 1991 Immunochemical demonstration of $\square 3$ isozyme of the Na,K-ATPase in human brain. Neurosci. Lett. 130: 37-40.

19. Peng JH, Zeng YC, and Parker JC Jr. 1992 Highly ouabain-sensitive 3 isoform $\mathrm{Na}, \mathrm{K}$-ATPase in human brain. J. Neurochem. 58 : 1180-1183.

20. Peng JH, McGeer PL, and McGeer EG. 1983 Antihuman brain choline acetyltransferase fragment antigen binding (Fab)-sepharose chromatography for enzyme purification. Neurochem. Ress. 8: 1481-1486. 